\title{
Nutritional content of supermarket ready meals and recipes by television chefs in the United Kingdom: cross sectional study
}

\author{
(C) (1) $(9)$ OPEN ACCESS
}

\author{
Simon Howard specialty registrar in public health ${ }^{1}$, Jean Adams senior lecturer in public health ${ }^{2}$, \\ Martin White professor of public health ${ }^{2}$
}

${ }^{1}$ NHS Tees, Stockton on Tees TS17 6SG, UK; ${ }^{2}$ Fuse, UKCRC Centre for Translational Research in Public Health, Institute of Health and Society, Newcastle University, UK

\begin{abstract}
Objectives To compare the energy and macronutrient content of main meals created by television chefs with ready meals sold by supermarkets, and to compare both with nutritional guidelines published by the World Health Organization and UK Food Standards Agency.

Design Cross sectional study.

Setting Three supermarkets with the largest share of the grocery market in the United Kingdom, 2010.

Samples 100 main meal recipes from five bestselling cookery books by UK television chefs and 100 own brand ready meals from the three leading UK supermarkets.
\end{abstract}

Main outcome measures Number of meals for which the nutritional content complied with WHO recommendations, and the proportion of nutrients classified as red, amber, or green using the UK FSA's 'traffic light" system for labelling food.

Results No recipe or ready meal fully complied with the WHO recommendations. The ready meals were more likely to comply with the recommended proportions of energy derived from carbohydrate (18\% $v 6 \%, \mathrm{P}=0.01)$ and sugars $(83 \% \vee 81 \%, \mathrm{P}=0.05)$ and fibre density $(56 \%$ $v 14 \% \mathrm{P}<0.01)$. The recipes were more likely to comply with the recommended sodium density ( $36 \% v 4 \%, P<0.01)$, although salt used for seasoning was not assessed. The distributions of traffic light colours under the FSA's food labelling recommendations differed: the modal traffic light was red for the recipes (47\%) and green for ready meals (42\%). Overall, the recipes contained significantly more energy (2530 $\mathrm{kJ} v 2067 \mathrm{~kJ})$, protein $(37.5 \mathrm{~g} v 27.9 \mathrm{~g})$, fat $(27.1 \mathrm{~g} \mathrm{v} 17.2 \mathrm{~g})$, and saturated fat ( $9.2 \mathrm{~g} v 6.8 \mathrm{~g} ; \mathrm{P}<0.01$ for all) and significantly less fibre ( $3.3 \mathrm{~g} v 6.5 \mathrm{~g}, \mathrm{P}<0.01$ ) per portion than the ready meals.

Conclusions Neither recipes created by television chefs nor ready meals sold by three of the leading UK supermarkets complied with WHO recommendations. Recipes were less healthy than ready meals, containing significantly more energy, protein, fat, and saturated fat, and less fibre per portion than the ready meals.

\section{Introduction}

Overweight and obesity are major threats to public health globally. One estimate suggests that 1.46 billion adults worldwide were overweight in $2008,{ }^{1}$ and projections suggest that by 2020 over $70 \%$ of adults in the United Kingdom and United States will be overweight. ${ }^{2}$ This is likely to result in millions of additional cases of diabetes and heart disease and thousands of additional cases of cancer. ${ }^{2}$

In the United Kingdom, chefs who are popular on television programmes often advocate home cooking, and participants in UK studies have cited them as sources of cookery based knowledge. ${ }^{34}$ Cookery shows often appear in the weekly top 30 viewed television programmes, ${ }^{5}$ some cookery books by television chefs are among the all time bestselling non-fiction books in the United Kingdom, ${ }^{6}$ and a successful UK commercial television channel, Good Food, ${ }^{7}$ is dedicated to cookery. ${ }^{8}$ It is possible therefore that television chefs influence many peoples' diets, although the type and degree of this influence is unclear: no simple relation exists between an individual's food based knowledge and their home cooking practices. ${ }^{9}$ However, the popularity of television chefs suggests that their recipes form part of the nutritional landscape and yet no study has examined the nutritional content of their meals.

One alternative to cooking meals based on recipes is to use ready meals, more commonly known as "TV dinners" in the United States. ${ }^{10}$ The definition of a ready meals is inconsistent, but the food industry sometimes defines it as a preprepared main course that can be reheated in its container, requires no further ingredients, and needs only minimal preparation before 
consumption. ${ }^{11}$ According to the food industry, around $£ 9.5 \mathrm{bn}$ ( $€ 11.4 \mathrm{bn} ; \$ 15 \mathrm{bn}$ ) worth of ready meals are sold in western Europe each year, representing around $37 \%$ of the global market. ${ }^{12}$ The United Kingdom represents the largest share of sales of ready meals in Europe, accounting for almost $£ 2.5 \mathrm{bn}$ annually. ${ }^{12}{ }^{13}$ In $2003,77 \%$ of households responding to a survey by the UK's Food Standards Agency (FSA) stated that they consumed ready meals at least occasionally, and $28 \%$ described using them at least weekly, although a definition for ready meals was not stated. ${ }^{14}$ The ready meal market in the United States is less developed than that in the United Kingdom but is expanding, with some European manufacturers moving into the American market. ${ }^{15}{ }^{16}$ As with meals advocated by television chefs, no study has comprehensively examined the nutritional content of ready meals sold in UK supermarkets. A survey by the FSA in 2003 suggested that the salt content of ready meals was high, but the sample was not representative of the market. ${ }^{17}$ Although some studies have explored the nutritional content of "convenience foods" 18 they often use a broader definition than ready meals alone.

Recipes promoted by television chefs are sometimes presented as being healthy: both NHS Choices ${ }^{19}$ and Heart UK ${ }^{20}$ feature exemplar "healthy recipes" associated with named television chefs, and some hospital trusts have taken advice from television chefs when formulating supposedly healthy hospital meals. This may give the impression that meals cooked by television chefs are, generally, healthy. By comparison, ready meals are often criticised for being unhealthy. NHS Choices claims that "ready-made meals often contain less fruit and vegetables (and more fat and sugar) than the meals you'd cook for yourself.,"21 Both the US government's ChooseMyPlate initiative ${ }^{22}$ and the UK government's Change4Life initiative ${ }^{23}$ advise against frequent consumption of ready meals, despite no study having comprehensively assessed their nutritional content. We compared the energy, protein, carbohydrate, fat, sugar, fibre, and salt content of recipes devised by television chefs with those of standard range ready meals sold by supermarkets and determined whether the nutritional content complied with national and international recommendations.

\section{Methods}

We carried out a cross sectional analysis of the nutritional content of 100 main meals as described in recipes by television chefs and 100 standard ready meals sold by supermarkets as their own brand. Sample sizes were pragmatic but sufficient to ensure reasonable confidence limits for estimates (for example, $7.4 \%$ difference in energy content at the 5\% significance level). We included meals if they were designed to be eaten hot, they were not described as being suitable for special occasions only or for breakfast, they were not soups, they included substantive items from at least two of the EatWell groups of the FSA,${ }^{24}$ and the recommended serving size was at least $225 \mathrm{~g}$.

We chose these inclusion criteria to generate a comparable sample of ready meals and recipes created by television chefs that might be considered as typical main dishes for everyday consumption. We excluded soups because they are not always consumed as main dishes. ${ }^{25}{ }^{26}$ In restricting meals to those dishes including substantive items from at least two of the EatWell groups $^{24}$ and with a recommended serving size of at least 225 $\mathrm{g}$ we ensured that no items intended as side dishes (for example, prepared mashed potato, bubble and squeak) were inadvertently included-particularly in the ready meals sample.

\section{Selection of recipes by television chefs}

A television chef was defined as someone who had hosted at least one series on a UK terrestrial channel and had cooked in the programmes. We accessed recipes linked to these chefs in the most up to date books they had authored. To ensure external validity of the study we used a populist sample of recipe books. On 20 December 2010 we accessed the bestsellers chart through the food and drink category on Amazon (www.amazon.co.uk) and assessed the books for inclusion. We included the top five selling books identified on the cover as a television series tie-in, credited to a single television chef, and containing recipes for main course meals. From those meeting the inclusion criteria we selected a random sample of 100 recipes using randomly generated numbers in proportion to the number of eligible recipes in each book.

\section{Selection of ready meals}

For the category of own brand ready meals we included those sold by three large supermarket chains in the United Kingdom. Four supermarkets dominate the grocery market in the United Kingdom $^{27}$ : Tesco (30.6\% of grocery market), Asda (16.9\%), Sainsbury's (15.7\%), and Morrisons (11.3\%). We excluded Morrisons because its share varied considerably across the country (as low as $6 \%$ in some regions). ${ }^{27} 28$

Eligible ready meals were those produced by the supermarkets themselves (own brand), chilled, and bought within the container used for cooking the product. As we thought the term ready meal is commonly understood to imply a short preparation time, the eligible meals also had to have a recommended preparation time of 15 minutes or less (including heating).

Between 6 and 22 December 2010 we accessed online supermarket inventories to determine those ready meals sold by the included supermarkets that were potentially eligible for the study. Using randomly generated numbers in proportion to the number of meals sold by each supermarket we then selected a random sample of 100 ready meals that met the inclusion criteria.

\section{Nutritional content of included meals}

For each meal we collected information on the recommended number of servings (taken as the lower end of any stated range) and total energy $(\mathrm{kJ})$, protein $(\mathrm{g})$, carbohydrate $(\mathrm{g})$, sugar $(\mathrm{g})$, sodium $(\mathrm{mg})$, fat $(\mathrm{g})$, saturated fat $(\mathrm{g})$, and fibre $(\mathrm{mg})$ content. We also recorded the weight of each meal: for the recipes we used the total weight of the raw ingredients, whereas for the ready meals we recorded the total weight of the product as sold. Using WinDiets software, ${ }^{29}$ we calculated the nutritional content of the meals devised by the television chefs based on the raw ingredients stated in the recipes. When no exact matches could be found we substituted for the nearest available alternative- for example, the nutritional content of white rice used as a substitute for basmati rice. We excluded optional ingredients.

Because of the limited published data on the nutritional content of cooked foods we used the nutritional content of raw rather than cooked ingredients. As it is permissible for manufacturers to calculate the nutritional content of supermarket ready meals based on raw ingredients and to put this information on the packaging ${ }^{30}$ this also maximised comparability as far as possible.

We obtained data on the nutritional content of the ready meals from the supermarkets' websites. 


\section{Statistical analysis}

For each meal we calculated the nutritional content per portion by dividing the total content by the number of portions in the meal. Using the Mann-Whitney test we compared the total content per portion between the ready meals and the recipes.

We calculated the percentage of energy derived from each macronutrient for each meal and used the Mann-Whitney test to compare the differences between the groups of ready meals and recipes. Using $\chi^{2}$ tests we compared the percentage of energy derived from macronutrients in the meals and recipes with the nutrient intake goals for preventing diet related chronic diseases recommended by WHO. ${ }^{31}$

For each meal in both groups we assigned a "traffic light" colour for the four macronutrients (fat, saturated fat, sugar, and salt) according to a modified version of the 2007 FSA guidance on its recommended labelling scheme $\mathrm{e}^{32}$; as information on the proportion of sugar derived from such sources was not available we did not use the criterion allowing a higher total sugar content in situations where a high proportion of sugar is derived from natural sources. The traffic light system is used on the front of packaging to help consumers assess at a glance the fat, saturated fat, sugar, and salt content of meals, prompting them to make healthier dietary choices.

We considered comparing specific main course types (for example, chicken based dishes) or specific dishes (for example, lasagne) between the recipes and ready meals. However, it proved difficult to define both main course "types" and specific dishes. A combined approach also better reflected the balance of meals on offer between the two groups. It seems likely that consumers decide on whether to follow a recipe by a television chef or to use a ready meal before choosing the specific meal, making the balance of main courses on offer in each group important.

All statistical analyses were done in Minitab 15 (Minitab, Coventry, UK).

\section{Results}

The five included recipe books contained 651 recipes (table $1 \Downarrow)$. Of these, 193 (29.6\%) met the inclusion criteria. The supermarkets' websites listed 1404 products in their ready meal sections, of which 234 (16.1\%) met the inclusion criteria.

Table $2 \Downarrow$ summarises the median nutritional content per portion per meal separately for the recipes and ready meals. Per portion, the recipes contained significantly more energy, protein, fat, and saturated fat than the ready meals, and significantly less fibre.

Table $3 \Downarrow$ shows the median percentage of energy derived from macronutrients as well as fibre and sodium density for each type of meal. No recipe or ready meal met all of the WHO nutrient intake goals for preventing diet related diseases. ${ }^{31}$ Table 3 also shows the number and proportion of each meal type that met each nutrient specific WHO goal. More ready meals than recipes met the WHO goals for fibre density $(56 \% v 14 \%, \mathrm{P}<0.01)$ and percentage of energy derived from carbohydrate $(18 \% v 6 \%$, $\mathrm{P}=0.01)$ and fat $(37 \% \vee 24 \%, \mathrm{P}=0.05)$, but more ready meals than recipes exceeded the recommended sodium density $(96 \%$ $v 64 \%, \mathrm{P}<0.01$ ).

Table $4 \Downarrow$ shows the number of each traffic light colour assigned to the meals in each group according to FSA labelling criteria. ${ }^{32}$ The distribution of colours differed between the two groups. The recipes had more red and the ready meals more amber, but green was almost equal between the groups. The modal colour was red for the recipes and green for the ready meals.
The figure $\Downarrow$ shows simulated front of package labels for an average recipe and an average ready meal using a design based on FSA guidelines. ${ }^{32}$ For each macronutrient in this figure, the traffic light colours shown are the modal colour within each meal group, and the figures stated are the median value within each meal group. A similar approach to summarising the data has been used in previous studies. ${ }^{38}$

\section{Discussion}

Recipes devised by television chefs and own brand ready meals sold by three leading UK supermarket chains both tended to be high in protein, fat, saturated fat, and sodium, low in carbohydrate, and within the recommended range for sugar according to World Health Organization nutritional guidelines for the avoidance of diet related diseases. ${ }^{31}$ Meals based on television chef recipes were less healthy than ready meals, as significantly fewer were within the recommended ranges for fibre density and percentage of energy derived from carbohydrate and fat, and per portion they contained significantly more energy, protein, fat, and saturated fat and significantly less fibre. The recipes were also more likely to achieve red traffic light labels according to the criteria of the UK Food Standards Agency (FSA). ${ }^{32}$ Despite reported efforts from industry to reduce the salt content of meals, ${ }^{39}$ only $4 \%$ of the ready meals met the WHO recommendation.

\section{Strengths and weaknesses of the study}

This study is the first to explore the nutritional content of recipes created by television chefs and to examine comprehensively the nutritional value of own brand ready meals sold by supermarkets with the highest share of the grocery market in the United Kingdom.

To increase the external validity of our findings we used a populist sampling frame to identify both the recipes and the ready meals. However, the nutritional content of recipes varied substantially between individual recipe books (data available from the author), suggesting that a different selection process may have led to different findings. Selecting books that were bestsellers in the run-up to Christmas may have influenced the selection of recipes, and the transient nature of bestseller charts may challenge the representativeness of the sample. The size of the sample prevented subgroup analyses comparing individual chefs or supermarkets.

Although we designed the methods to ensure good comparability between the groups, it is difficult to assess the impact of the differing data sources used for the selection of the ready meals and recipes. In the United Kingdom, the published nutritional data used for analysis of ready meals is permitted by law to vary by $20 \%$ from the true macronutrient values. ${ }^{30}$ Systematic variation from the true macronutrient value of the foods could be a source of bias in this study. However, our analyses were based on the most accurate data currently available to the public. We may have systematically underestimated the values for salt within the recipe group. As salt was often listed as an optional ingredient to be added "to taste," we excluded it from our analyses. Therefore the findings for salt should be interpreted with caution. Research evidence is lacking as to whether consumers typically season ready meals with salt in the same way as they do for home cooked meals.

We did not examine the micronutrient content of the ready meals or recipes or the presence of artificial preservatives, flavours, colourings, or stabilisers. These may be additional important aspects to consider when judging the overall healthiness of a 
food. Although micronutrients do not feature in the FSA traffic light labelling, they do appear in alternative labelling schemes such as that suggested by Bittman. ${ }^{40}$ Inclusion of this information could be considered as the government revises the standards for traffic light labelling. ${ }^{41}$ Furthermore, the WHO standards used are based on average intake over time rather than on individual meals, and it is not necessarily the case that one main course should meet these standards. However, in the absence of international criteria for the nutritional content of individual meals, these standards are the best currently available and have been used previously for assessment of individual products. ${ }^{42}{ }^{43}$

\section{Comparison with other studies}

The levels of salt found in ready meals in this study are comparable to those of another study carried out in $2008 .^{44}$ However, both sets of results contrast noticeably with an investigation by the FSA in $2003,{ }^{17}$ which found high salt levels in $83 \%$ of ready meals sold by supermarkets. Six products appear both in the FSA sample and in the sample in this study. In the survey by the FSA, all six products contained over $2.4 \mathrm{~g}$ of salt per portion, which represents $40 \%$ of the recommended daily allowance of salt. ${ }^{17}$ In this study, carried out seven years later, only two exceeded this threshold. This provides some evidence that reformulation since 2003 may have had an impact on the salt content of supermarket ready meals, although only $4 \%$ of ready meals met the WHO recommendation on sodium density.

\section{Unanswered questions and future research}

This study's external validity is limited by the inclusion of items from only three supermarkets and five recipe books. Although our samples were intended to be populist, they may not reflect the market as a whole. A comprehensive examination of the nutritional value of all ready meals sold in UK supermarkets and a wider selection of recipe books would help to shed further light on the nutritional state of foods sold generally.

Although television chefs are one source of recipes and information about home cooking, their meals are not representative of all home cooking practices. Personal home cooking practices are complex ${ }^{9}$ : people may cook without recipes, use recipes in older books or from other sources, or prepare meals containing both preprepared and freshly cooked elements. Studies examining people's actual food preparation and eating habits could provide clearer data on the comparative nutritional value of preprepared and freshly cooked items actually consumed in the population.

\section{Meaning of the study and implications}

This study shows that neither recipes created by popular television chefs nor ready meals produced by three leading UK supermarket chains meet national or international nutritional standards for a balanced diet. The recipes seemed to be less healthy than the ready meals on several metrics. Maximum nutritional benefit is likely to be derived from home cooking of nutritionally balanced recipes primarily using raw ingredients, rather than relying on ready meals or recipes by television chefs. Further reformulation of ready meals in line with international nutritional guidelines, and collaboration with television chefs to improve the nutritional quality of their recipes, may also help consumers to achieve a balanced diet.

In the United Kingdom advertisements of foods classified as high in fat, salt, or sugar are prohibited during programming likely to appeal to children, ${ }^{45}$ and a $9 \mathrm{pm}$ watershed for advertising such foods has been advocated. ${ }^{46}$ No restrictions apply to the content of programmes with television chefs. For consistency, the nutritional content of all food portrayed on television, including that in programmes with television chefs, should be considered. Inclusion of consistent nutritional information that is easy to understand in recipe books, similar to that advocated for labelling on the front of food packaging, ${ }^{32}$ should also be considered.

Practitioners should take care when advising patients on improvements to their diet. Recommendations to cook from scratch rather than eat ready meals needs to be set in the context of detailed nutritional advice.

This research was undertaken by $\mathrm{SH}$ (supervised by JA and MW) in partial fulfillment of the requirements for the MSc in Public Health and Health Services Research at Newcastle University (degree awarded December 2011).

Contributors: SH conceived the study, collected and analysed the data, and drafted the manuscript. All authors contributed to the study design and interpretation of results and commented on successive drafts of the manuscript, and will act as guarantors.

Funding: At the time this research was done, MW was partly and JA fully supported by Fuse, the Centre for Translational Research in Public Health, a UK Clinical Research Collaboration (UKCRC) Public Health Research Centre of Excellence. Fuse receives funding from the British Heart Foundation, Cancer Research UK, Economic and Social Research Council (No RES-590-38-0003), Medical Research Council, and the National Institute for Health Research, under the auspices of UKCRC. Views expressed do not necessarily represent those of the funders.

Competing interests: All authors have completed the ICMJE uniform disclosure form at www.icmje.org/coi_disclosure.pdf (available on request from the corresponding author) and declare: no support from any companies for the submitted work; no relationships with any companies that might have an interest in the submitted work in the previous three years; and no non-financial interests that may be relevant to the submitted work.

Ethical approval: Not required.

Data sharing: The full dataset is available from the corresponding author at simonhoward@nhs.net.

1 Finucane MM, Stevens GA, Cowan MJ, Danaei G, Lin JK, Paciorek CJ, et al. National, regional, and global trends in body-mass index since 1980: systematic analysis of health examination surveys and epidemiological studies with 960 country-years and $9 \cdot 1$ million participants. Lancet 2011;377:557-67.

2 Wang YC, McPherson K, Marsh T, Gortmaker SL, Brown M. Health and economic burden of the projected obesity trends in the USA and the UK. Lancet 2011;378:815-25.

3 Caraher M, Lang T, Dixon P. The influence of TV and celebrity chefs on public attitudes and behavior among the English public. J Study Food Soc 2000;4:27-46.

4 Reilly J. The impact of the media on food choice. Shepherd R, Ratts M, eds. The psychology of food choice. CABI, 2006.

5 Broadcasters' Audience Research Board. Weekly top 30 programmes. BARB.

6 BBC News. Jamie Oliver's 30-Minute Meals breaks sales record. BBC News Online. 2010. www.bbc.co.uk/news/uk-11957627.

www.bbc.co.uk/news/uk-11957627.
Sweney M. UKTV channel to rebrand as Good Food. The Guardian. 2009. www.guardian. co.uk/media/2009/may/13/uktv-good-food-bbc-worldwide.

8 The Guardian. Good Food: TV listings guide. The Guardian. 2010. http://tvlistings.guardian. co.uk/.

9 Short F. Domestic cooking practices and cooking skills: findings from an English study. Food Serv Technol 2003;3(3-4):177-85.

10 Oxford English Dictionary. TV dinner. Oxford English dictionary. Oxford University Press, 2008.

11 Mintel Oxygen. Chilled and frozen ready meals: issues in the market. 2010. http://oxygen. mintel.com/sinatra/oxygen/display/id $=526814$

12 RTS Resources. Western Europe: ready meals 2010. www.readymealsinfo.com/ readymealsinfo.com/reports/WesternEuropeReadyMeals2010.pdf.

13 Chilled Food Association. The history of UK chilled foods. 2010. www.chilledfood.org MEDIA.

14 Food Standards Agency. The ready meals market. FSA, 2003.

15 Corrigan T. Is America ready for British ready-meals? Telegraph Online. 2010. http:// blogs.telegraph.co.uk/finance/tracycorrigan/100006264/is-america-ready-for-british-readyblogs.tel.
meals/.

16 Greencore Group. Greencore USA. 2010. www.greencore.ie/content.asp?topic=greencore north_america\&page $=359$.

17 Food Standards Agency. Salt in ready meals survey findings. 2003. www.food.gov.uk/ multimedia/faq/readymealqanda/.

18 Alexy U, Libuda L, Mersmann S, Kersting M. Convenience foods in children's diets and associations with dietary quality and body weight status. Eur J Clin Nutr 2011;65:160-6. 


\section{What is already known on this topic}

Supermarket ready meals and recipes devised by television chefs may have an impact on dietary intake

The nutritional content of ready meals and recipes by television chefs have not been assessed comprehensively

\section{What this study adds}

Recipes devised by popular television chefs contained significantly more energy, protein, fat, and saturated fat and less fibre per portion than ready meals

Most cookery books do not provide nutritional information on recipes, which could help to inform consumers

Consideration should be given to regulation of the recipes demonstrated by television chefs similar to that limiting advertisement of foods classified as high in fat, salt, or sugar

19 NHS Choices. Quick and healthy meals. 2010. www.nhs.uk/Livewell/women1839/Pages/ celebhealthyrecipes.aspx.

20 UK Heart. Celebrity chefs tea party recipes. 2012. http://heartuk.org.uk/healthy-living/ tasty-recipes/celebrity-chefs-recipes-Tea-Party-recipes.

21 NHS Choices. 5 a day on the run. 2011. www.nhs.uk/Livewell/5ADAY/Pages/ 5ADAYontherun.aspx.

22 USDA. Cook more often at home. 2011. www.choosemyplate.gov/weight-managementcalories/weight-management/better-choices/cook-home.html.

23 Department of Health. Change4Life marketing strategy. 2009. www.nhs.uk/Change4Life/ supporter-resources/downloads/Change4Life_Marketing\%20Strategy_April09.pdf.

24 NHS Choices. The eatwell plate. www.nhs.uk/Livewell/Goodfood/Pages/eatwell-plate. aspx.

25 Johnson W, Corrigan S, Schlundt D, Dubbert P. Dietary restraint and eating behavior in the natural environment. Addict Behav 1990;15:285-90.

26 Dubbert $\mathrm{P}$, Johnson $\mathrm{W}$, Schlundt $\mathrm{D}$, Montague $\mathrm{N}$. The influence of caloric information on cafeteria food choices. J Appl Behav Anal 1984;17:85-92.

27 Garner E. Tesco share turnaround (plus an update on grocery price inflation). TNS Global Website. 2009. www.marketresearchworld.net/index.php?option=com content\&task=view\& id $=2865 \&$ ltemid $=77$.

28 Morrisons. Market overview: annual report and financial statements 2010. Morrison Supermarkets. www.morrisons.co.uk/Corporate/2010/AnnualReport/download-centre/ PDFs/full.pdf.

29 Windiets. WinDiets dietary analysis. 2012. www.windiets.com/.

30 LACORS. Update on nutrition labelling tolerances. 2010. www.lacors.gov.uk/lacors/ ContentDetails.aspx?id=24490.

31 World Health Organization. Population nutrient intake goals for preventing diet-related chronic diseases. Diet, nutrition and the prevention of chronic diseases. WHO, 2003;54-9.

32 Food Standards Agency. Front-of-pack traffic light signpost labeling: technical guidance. 2007. www.food.gov.uk/multimedia/pdfs/frontofpackguidance2.pdf.

33 Oliver J. Jamie's 30 minute meals. Michael Joseph, 2010.

34 Pascale L. Baking made easy. HarperCollins, 2011.

35 Oliver J. Jamie's ministry of food. Michael Joseph, 2008.
36 Lawson N. Kitchen: recipes from the heart of the home. Chatto and Windus, 2010.

37 Fearnley-Whittingstall H. River Cottage everyday. Bloomsbury, 2009.

38 Harrison K, Marske A. Nutritional content of foods advertised during the television programs children watch most. Am J Public Health 2005;95:1568-74

39 Consensus Action on Salt and Health. Food industry progress. 2012. www.actiononsalt. org.uk/news/industry/31988.html.

40 Bittman M, ed. My dream food label. The New York Times. 2012. www.nytimes.com/2012 10/14/opinion/sunday/bittman-my-dream-food-label.html.

41 Triggle N. Food labelling: consistent system "to start next year." BBC News Online. 2012 www.bbc.co.uk/news/health-20050420.

42 Adams J, Tyrrell R, White M. Do television food advertisements portray advertised foods in a "healthy" food context? Br J Nutr 2011;105:810-5

43 Adams $\mathrm{J}$, White $\mathrm{M}$. Socio-economic and gender differences in nutritional content of foods advertised in popular UK weekly magazines. Eur J Public Health 2009;19:144-9.

44 Hopkins J, Thomas J. Salt content of ready meals commonly consumed by older people. J Hum Nutr Diet 2008;21:389-90.

45 Ofcom. HFSS advertising restrictions-final review. 2010.

46 British Heart Foundation. Policy statement: unhealthy food and drink marketing and children. 2012. Document can be found on the British Heart Foundation website (http:// tinyurl.com/cvfheg4).

\section{Accepted: 31 October 2012}

\section{Cite this as: BMJ 2012;345:e7607}

This is an open-access article distributed under the terms of the Creative Commons Attribution Non-commercial License, which permits use, distribution, and reproduction in any medium, provided the original work is properly cited, the use is non commercial and is otherwise in compliance with the license. See: http://creativecommons.org/licenses/bync/2.0/ and http://creativecommons.org/licenses/by-nc/2.0/legalcode. 


\section{Tables}

Table 1 | Number of recipes and supermarket meals assessed for eligibility and included in analyses

Sources of meals

No of recipes/meals No (\%) eligible No (\%) included

Television chef recipes:

\begin{tabular}{lccc}
\hline 30 Minute Meals, Jamie Oliver & & & \\
Baking Made Easy, Lorraine Pascale $^{34}$ & 50 & $(98.0)$ & $25(51.0)$ \\
\hline Ministry of Food, Jamie Oliver $^{35}$ & 110 & $13(11.8)$ & $7(53.8)$ \\
\hline Kitchen, Nigella Lawson $^{36}$ & 154 & $43(27.9)$ & $22(51.2)$ \\
\hline River Cottage Everyday, Hugh Fearnley-Whittingstall ${ }^{37}$ & 145 & $48(33.1)$ & $25(52.0)$ \\
\hline Total & 192 & $40(20.8)$ & $21(52.5)$ \\
\hline Own brand ready meals: & 651 & $193(29.6)$ & $100(51.82)$ \\
\hline Asda & & & \\
\hline Sainsbury's & 410 & $78(19.0)$ & $33(42.3)$ \\
\hline Tesco & 514 & $58(11.3)$ & $25(43.1)$ \\
\hline Total & 480 & $98(20.4)$ & $42(42.9)$ \\
\hline
\end{tabular}


Table 2| Nutritional content per portion of 100 recipes created by television chefs and 100 supermarket ready meals, United Kingdom, 2010

\begin{tabular}{lcccc} 
& \multicolumn{3}{c}{ Median (interquartile range) } & \\
\cline { 2 - 5 } Nutritional content & Recipes & Ready meals & Total & P value* \\
\cline { 2 - 5 } Energy (kJ) & $2530(2027-3240)$ & $2067(1716-2563)$ & $2285(1776-2817)$ & $<0.01$ \\
\hline Protein (g) & $37.5(26.7-50.0)$ & $27.9(23.3-30.0)$ & $31.6(24.0-40.2)$ & $<0.01$ \\
\hline Carbohydrate (g) & $49.5(23.5-68.1)$ & $51.1(41.9-67.4)$ & $50.8(34.3-67.6)$ & 0.06 \\
\hline Sugar (g) & $8.3(5.0-12.6)$ & $6.8(4.2-10.9)$ & $7.6(4.5-12.0)$ & 0.09 \\
\hline Sodium (mg) & $658(369-1035)$ & $800(607-1000)$ & $780(508-1000)$ & 0.05 \\
\hline Fat (g) & $27.1(16.8-40.4)$ & $17.2(12.3-23.7)$ & $21.6(14.0-31.0)$ & $<0.01$ \\
\hline Saturated fat (g) & $9.2(4.9-15.9)$ & $6.8(3.8-11.6)$ & $7.9(4.3-13.6)$ & $<0.01$ \\
\hline Fibre (g) & $3.3(2.0-5.7)$ & $6.5(4.8-8.5)$ & $5.1(2.9-7.6)$ & $<0.01$ \\
\hline & & & &
\end{tabular}

*Mann-Whitney test comparing recipes with ready meals. 
Table 3| Median percentage energy derived from macronutrients, and sodium and fibre density, of 100 television chef recipes and 100 supermarket ready meals, United Kingdom, 2010

\begin{tabular}{|c|c|c|c|c|c|c|c|c|c|}
\hline \multirow[b]{2}{*}{$\begin{array}{l}\text { Nutritional } \\
\text { content }\end{array}$} & \multicolumn{2}{|c|}{ Recipes $(n=100)$} & \multicolumn{2}{|c|}{ Ready meals $(n=100)$} & \multicolumn{2}{|c|}{ All items } & \multirow[b]{2}{*}{$\begin{array}{l}\text { WHO } \\
\text { range }\end{array}$} & \multirow[b]{2}{*}{$x^{2 \star}$} & \multirow[b]{2}{*}{ P value } \\
\hline & $\begin{array}{c}\text { Median } \\
\text { (interquartile } \\
\text { range) }\end{array}$ & $\begin{array}{l}\text { \% within } \\
\text { WHO range }\end{array}$ & $\begin{array}{c}\text { Median } \\
\text { (interquartile } \\
\text { range) }\end{array}$ & $\begin{array}{l}\text { \% within } \\
\text { WHO range }\end{array}$ & $\begin{array}{c}\text { Median } \\
\text { (interquartile } \\
\text { range) }\end{array}$ & $\begin{array}{l}\text { No (\%) within } \\
\text { WHO range }\end{array}$ & & & \\
\hline \multicolumn{10}{|l|}{$\begin{array}{l}\text { Macronutrient } \\
\text { (\% energy): }\end{array}$} \\
\hline Protein & $23.8(18.8-33.9)$ & 7 & $22.7(18.2-27.3)$ & 9 & $22.9(18.5-30.5)$ & $16(8)$ & $10-15$ & 0.27 & 0.60 \\
\hline Carbohydrate & $31.6(19.0-42.1)$ & 6 & $42.9(37.0-52.5)$ & 18 & $38.7(28.9-48.4)$ & $24(12)$ & $55-75$ & 6.82 & 0.01 \\
\hline Sugars & $5.3(3.3-8.8)$ & 81 & $5.7(3.8-8.7)$ & 83 & $5.5(3.3-8.8)$ & $164(82)$ & $<10$ & 0.14 & 0.71 \\
\hline Fat & $42.2(30.1-54.0)$ & 24 & $32.4(25.9-39.2)$ & 37 & $35.6(27.9-45.9)$ & $61(31)$ & $15-30$ & 3.99 & 0.05 \\
\hline Saturated fat & $14.9(9.0-20.9)$ & 33 & $13.9(7.8-18.7)$ & 34 & $14.0(8.0-19.8)$ & $67(34)$ & $<10$ & 0.02 & 0.88 \\
\hline $\begin{array}{l}\text { Fibre density } \\
(\mathrm{g} / \mathrm{MJ})\end{array}$ & $1.4(0.8-2.6)$ & 14 & $3.2(2.4-4.4)$ & 56 & $2.5(1.4-3.7)$ & $70(35)$ & $>3.0 \dagger$ & 38.77 & $<0.01$ \\
\hline $\begin{array}{l}\text { Sodium density } \\
\text { (g/MJ) }\end{array}$ & $0.2(0.1-0.4)$ & 36 & $0.4(0.3-0.5)$ & 4 & $0.4(0.2-0.5)$ & $40(20)$ & $<0.2 \ddagger$ & 32.00 & $<0.01$ \\
\hline \multicolumn{10}{|c|}{$\begin{array}{l}{ }^{*} x^{2} \text { tests with one degree of freedom comparing proportion of recipes with proportion of ready meals in World Health Organization range. } \\
\text { †Based on } 8.4 \mathrm{MJ} / \text { day ( } 2000 \mathrm{kcal} / \text { day) diet and recommended daily fibre intake of }>25 \mathrm{~g} \text {. }\end{array}$} \\
\hline
\end{tabular}


Table 4| Traffic light assessment according to modified Food Standards Agency guidelines ${ }^{32}$ for 100 recipes by television chefs and 100 supermarket ready meals, United Kingdom, 2010

No for recipes No for ready meals

Macronutrients Red Amber Green Red Amber Green

\begin{tabular}{lcccccc} 
Sugar & 17 & 0 & 83 & 11 & 0 & 89 \\
\hline Fat & 68 & 17 & 15 & 37 & 39 & 24 \\
\hline Saturated fat & 71 & 1 & 28 & 56 & 1 & 43 \\
\hline Salt & 31 & 28 & 41 & 30 & 60 & 10 \\
\hline Totals & 187 & 46 & 167 & 134 & 100 & 166
\end{tabular}




\section{Figure}

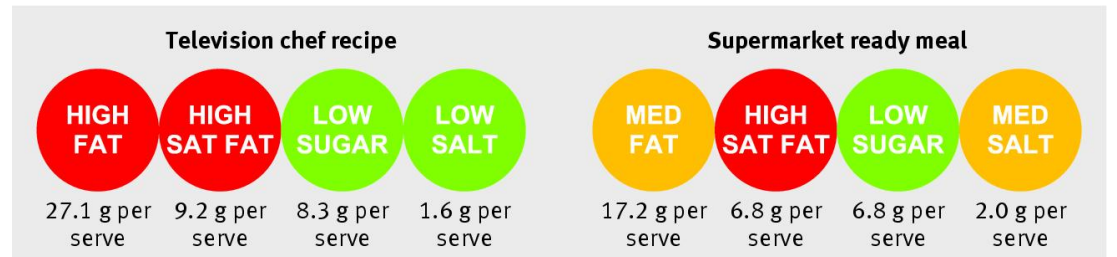

Simulated front of package labels for an average recipe created by a television chef and an own brand supermarket ready meal, based on guidelines from the FSA ${ }^{32}$ 